\title{
Probability of Paying Zakat from Micro Financing Project Returns
}

\author{
Jarita Duasa ${ }^{1 *}$, Nur Hidayah Zainal ${ }^{2}$ \\ ${ }^{*}$ Corresponding author
}

\begin{abstract}
The study aims to investigate the probability of paying zakat among participants or recipients of micro-finance scheme of Amanah Ikhtiar Malaysia. A survey is conducted on participants of Amanah Ikhtiar Malaysia scheme using convenience sampling in Perak and Kelantan. Data from the survey are analyzed using descriptive statistics and logistic regression. The results show that higher probability of paying zakat among respondents determined by small household size, lower per capita income, higher education level and those living in Perak. Thus, efforts should be taken by zakat institutions to well develop good and efficient methods of zakat collection among the participants specifically among low educated and higher incomelreturn of the projects.
\end{abstract}

Keywords: zakat, microfinance, Amanah Ikhtiar Malaysia, Logit regression

JEL Classification: C31, C83, D64, I39, G23

\begin{abstract}
Abstrak. Penelitian ini bertujuan untuk menginvestigasi kemungkinan pembayaran zakat di kalangan peserta atau penerima skema keuangan mikro dari Amanah Ikhtiar Malaysia. Survei dilakukan terhadap peserta skema Amanah Ikhtiar Malaysia dengan menggunakan convenience sampling di Perak dan Kelantan. Data dari survei dianalisis menggunakan statistik deskriptif dan regresi logistik. Hasil penelitian menunjukkan bahwa probabilitas yang lebih tinggi untuk membayar zakat di kalangan responden sangat ditentukan oleh ukuran rumah tangga kecil, pendapatan per kapita yang lebih rendah, tingkat pendidikan yang lebih tinggi dan mereka yang tinggal di Perak. Oleh karena itu, lembaga-lembaga zakat perlu diupayakan untuk mengembangkan metode penghimpunan zakat yang baik dan efisien di kalangan peserta, khususnya di kalangan yang berpendidikan rendah dan berpenghasilan/pengembalian proyek yang lebih tinggi.
\end{abstract}

Kata Kunci: zakat, keuangan mikro, Amanah Ikhtiar Malaysia, regresi logit

\section{How to Cite:}

Duasa, J., \& Zainal, N. H. (2020). Probability of Paying Zakat from Micro Financing Project Return. Etikonomi: Jurnal Ekonomi, 19(2), 333 - 348. https://doi.org/10.15408/etk.v19i2.15113. 


\section{Introduction}

In an attempt to reduce poverty and income disparities in Malaysia, the government of Malaysia has adopting microfinance as one of the objectives in launching New Economic Policy (NEP). In some countries, microfinance has been seen as an important tool to help the low-income group of the society in starting up a business and as a way out from poverty (Kassim et al., 2019). Malaysia microfinance landscape has benefited more than one million micro enterprises in the country (The Star, 2017). The group of society that excluded from the capitalist based system now is able to earned capital financing and creates their income despite of not having collateral.

Historically, in 1976, Muhamad Yunus had introduced micro-credit approach in Bangladesh to eradicate poverty and since then, this approach was used in many countries all over the world. Similar program first conducted by David Gibbons and Sukor Kasim in Malaysia in 1986 under Universiti Sains Malaysia (USM). This project was known as Projek Ikhtiar, which later known as 'Amanah Ikhtiar Malayasia' (AIM). It was launched as Malaysian model of Grameen Bank’s approach. Islamic Economic Development Foundation of Malaysia, Asia-Pacific Development Centre and the Selangor State Government funded the project. It was conducted by USM under the Centre for Policy Research of USM to reduce rural poverty level by providing micro-credit to the poor. Specifically, the goal of micro-credit scheme is to increase income and strengthen the living condition of the poor.

The expansion of AIM is basically assisting the poor who rarely involved in banking activities. The poor are normally lack of capital and thus unable to improve their quality of life. The pioneer project implemented in the northwestern area of Selangor for two and a half years. There were 373 poor households received their first loan. At least 90 percent repayments made by the participants which include loan capital and cost of financing at the end of the Projek Ikhtiar. The outcomes proved that the program was successful. The participants based on their skills and experiences conducted several projects using these funds. Among them are retail shops, farmers market, restaurant, rice, vegetable and animal farming. Since most of the AIM participants are Muslims among the Malays, it is perceived that they are obliged to pay zakat from the incomes received of the project scheme involved.

Zakat is one of the five pillars of Islam that basically a form of material and spiritual worship. The objective of paying zakat is to cleanse the wealth and positions by contributing a certain amount of net income that exceed nisab per year to the poor and needy. The term zakat itself means increase, purification and blessing. Thus, it aims at raising grace, purification and good works (Hafidhuddin, 2002). According to Al-Qardawi (1993), there are twenty-seventh places in the holy Quran mentioning on this intelligence obligation and thirty times in the Quran zakat is associated with prayers. This necessity is emphasized in the number of the hadiths. Apart from a compulsory worship, zakat has socio-economic goals. Zakat funds could act as social security in Islam that will guarantee provisions for the needy and weak people in the society (Ab Rahman \& Omar, 2010). It can also become a pool of funds for financing development activities in developing countries like Bangladesh, thus reducing the reliance on foreign aids (Hassan, 2010). 
Most importantly, zakat is one of the key measures for poverty eradication (Hassan, 2010). The successful story of zakat in alleviating poverty has been proven during the era of Caliph Umar bin Abdul Aziz where they couldn't find any zakat recipients in the country at that time (Ayuniyyah, 2011). If it is well-managed according to the sharia, it can be part of a long-term strategy to alleviate poverty which may includes development projects, educational services, and health care services for the asnaf (Hassan, 2010; Abdullah, 2010). This is agreed with study by Furqani et al. (2018), which believe zakat can solve for poverty and economic inequality in Indonesia. Therefore, it has a very important position in the development of the Muslim community.

A true Muslim who believes in Allah and the Prophet (PBUH) will constantly protect his imaan by fulfilling the obligations due upon him. When a Muslim pays zakat, it is a sign that he is striving to become a servant with strong faith to Allah and becoming a true brother in Islam to other Muslims who are in need (Ab Rahman \& Omar, 2010). Thus, through zakat, not only it fulfills sharia requirement and preserves aqidah, but it also strengthen the Muslim brotherhood since the social gap between the rich and the poor has been reduced. In addition to the worship factor, the individual understanding on Islamic rules will motivate people to fulfill the obligation of paying zakat.

Immediate payment of zakat is encouraged by majority of Muslim jurists (Abdullah \& Wan Ahmad, 2012; Aidit, 1998; and Al-Qardawi, 1998) argued that the inability to pay zakat is mainly due to the level of faith of individuals to perform religious obligations. Meanwhile, a study by Bakar \& Rashid (2010) showed that understanding about Islamic principles in particular individuals understanding about the conception of property and wealth in Islam becomes the main factor for the willingness to pay zakat. Here, one will perform the obligation of paying zakat if he or she believes that the property he or she owned is only temporarily and Allah is the only and absolute owner of all things in the heaven and the earth. Besides, Reinstein (2006) stated that religious faith is an important determinant of religious and secular giving. This study consistent with Lunn et al. (2001), that also agreed that there is positive relationship between religious inclusion and religious participation. They found that those who went to church regularly and conservative Presbyterians would give more. Abdullah \& Sapiei (2018) mentioned that religiosity level of a person significantly influenced zakat compliance yet a formal Islamic educational background had no significant influence on the tendency to pay zakat. Mokhtara et al. (2018) also put a greater concern on the religiosity level of zakat payers. Religiosity level significantly affects zakat payments especially to those with high level of knowledge and practice of Islam in their daily life.

Other than one's level of religious faith and knowledge regarding zakat, confidence and trust in the zakat institutions also play an important role in influencing people to pay zakat (Mujiyati et al., 2010; Ali et al., 2018; Othman et al., 2018). Saad et al. (2020) measure the business zakat compliance behavior and found out that for individuals opting to pay zakat, they must have positive attitude towards zakat payment. This positive attitude comes from their knowledge on zakat, the attitude to not evade zakat payment and attitude towards moral reasoning. Thus, zakat institution should put a clear positive method and promotions in zakat collection without unintentionally promote zakat evasion. This idea similar with 
Saad et al (2019) in the discussion on the importance of increasing the knowledge and selfconfidence of zakat payers, and so higher numbers of interaction between zakat institutions front staff with the zakat payers. These three indicators will provide a positive behavior for zakat payers to pay zakat. It is a fact that there is no specific law to force zakat payment on those who are eligible. Thus, a community awareness and willingness to pay zakat is important to be pursued. Khamis \& Yahya (2015), however, stated that law enforcement influence Small Medium Enterprise's (SMEs) entrepreneurs to comply with business zakat payments. Thus, even though there exist people who try to evade zakat payment, through the law enforcement zakat collection could be maximized.

Cokrohadisumarto et al. (2019) discussed four main indicators to increase zakat payment namely; knowledge on zakat, credibility of zakat institutions, role of information and role of religious leaders. These four indicators sum up could increase the amount of zakat payment. Ghani et al. (2018) highlighted the importance of trust among zakat payers towards zakat institutions. Zakat payers tend to evade zakat if there is lack of trust to the zakat institutions and if there is misunderstanding on the zakat distribution by the said institution. Nevertheless, zakat is still one pillar of Islam and no matter how zakat payers tried to evade it, they will still be held accountable later in the hereafter. Firdaus et.al. (2012) conclude that Muslims who are paying zakat monthly and yearly tend to have stronger faith, self-esteem, sacrifice and appreciation. The preferred place to pay for zakat / charity also affects the monthly wage payment preferences of the participants. Those who pay zakat to official institutions have a good decision about the performance of the institution. However, they found that the perceptions of those who pay zakat to formal or informal institutions are indifferent. This study also predicted the potential of zakat collection in Indonesia and explored the relationship between zakat payments and demographic variables. The finding is that around 217 trillion rupiahs could be the sum of various potential zakat collections in Indonesia. This figure equals to $3.4 \%$ of Indonesia's GDP in 2010. The study also found that occupation, income and education are important determinants of number of participation and the choice of place while paying zakat and charity.

Other research examined the demographic influences towards Muslims behavior in paying zakat on income are such as Ali et al. (2003), Kamil (2005), Wahid et al. (2005b) and Sanusi et al. (2005). Demographic factors that have been researched include gender, age, marital status, education level, number of dependents and income level. Wahid et al. (2005b), for example, tested thirteen factors that might influence the payment or nonpayment of zakat on income in Malaysia. Using logistic regression analysis, they found that five factors significantly influence the payment of zakat on income. Those are age, marital status, education level, income level and payment through salary deduction mechanism. Additionally, it is found that working female is more likely to pay zakat on income. Kamil (2005) tested the influence of the so-called intrinsic motivational factors of individual Muslim towards the compliance behavior of zakat on employment income. Among the intrinsic motivational factors included are perceived service quality, exposure on zakat promotional campaign, knowledge on zakat on income and religiosity. It is found that three variables, i.e. perceived service quality, level of zakat knowledge, level of exposure 
to zakat promotional campaign, to be significantly related to the compliance behavior in a positive direction. Another variable i.e. religiosity was found to have a negative correlation with compliance behavior.

In addition, Nor Ghani et al. (2001) tested whether factors like privatization of zakat institution, awareness regarding the zakat obligation, income growth and the rate of growth of zakat base population have any impact on zakat collection. They concluded that privatization has no significant impact on zakat collection, while the remaining three factors contributed to the differences in the zakat collection performance. Studies done on public institution of higher learning (IHLs) conducted by Ali et al. (2003) and Sanusi et al. (2005). Ali et al. (2003) surveyed employees of National University of Malaysia (UKM) and found six factors significantly influence their behavior on zakat income payment.

These factors include gender, number of dependents, education level, and knowledge on zakat on income, knowledge on Islam and level of piety (iman). However, factors like education level and knowledge on zakat on income negatively impact the zakat on income behavior while the remaining factors are positively related. Other studies that also discussed about the factors that influence zakat compliance behavior focusing on the demographic variables such as gender, age, marital status, education and income level are Ismail et al. (2012), Idris (2006) and Wahid et al. (2005a). Thus, socio-economic status could be regarded as important determinant of zakat compliance behavior among Muslims.

In general, many of the previous studies that tested the demographic factors affecting the zakat payment behavior are focused on general Muslims. To the knowledge of authors, none of the previous studies mainly focus on the respondents who are among the poor, particularly those who are assisted through the micro financing programs. Since the program's objective is to pull out the participants from the so-called poverty circle, the successfulness of the program might not block them to perform the obligation to pay zakat as Muslim. Thus, it is important to explore the probability of these microfinance recipients to pay zakat from income that they obtained under the scheme.

The present study, thus, looks at the probability of paying zakat among members of AIM. These participants of AIM project are those who received micro-credit from AIM to fund micro and small businesses. The study is outlined as following: Section 1 discusses a background of microfinance and zakat as well as review of previous studies. In section 2, data collected and methods used in the study are explained. Section 3 aims to display and discuss the results of study and Section 4 concludes the study and outline policy implications.

\section{Methods}

In this study, the respondents of the survey conducted are participants who received credits as loan from AIM to fund activities that generate income. The sample respondents are AIM participants in Perak and Kelantan. These two states are selected as they have large number of participants. Two stages of stratification involved in selecting the sample respondents. First, two areas from each state are chosen which are Kuala Kangsar and Teluk Intan in Perak and Kota Bharu and Tumpat in Kelantan. Second, from each area, respondents 
are randomly selected from different centers (called 'pusat' or centre), which are AIM branch offices. The present study is able to collect 1,961 usable responses from both states. The variables developed in the study are basically from the responses of survey questions. These variables are listed and defined in Table 1.

Table 1. Variables and Definitions

\begin{tabular}{|c|c|}
\hline Variable & Definition/description \\
\hline Marital status & $\begin{array}{l}\text { A dummy variable is used for marital status which is } 1 \text { represents married } \\
\text { respondents and } 0 \text { represents non-married or divorced }\end{array}$ \\
\hline Age & Age of respondents (year) \\
\hline Level of education & $\begin{array}{l}\text { The education attainment of respondent that is ranged from 'no education at all' } \\
\text { (1) to the highest level of education, that is, 'post-graduate level' (5). }\end{array}$ \\
\hline State & $\begin{array}{l}\text { A dummy variable that records the state where the respondents is living. Value } 1 \\
\text { is coded for those live in Kelantan and value } 0 \text { is for those live in Perak. }\end{array}$ \\
\hline Household size & Total number of persons living in similar home \\
\hline Gender & A dummy variable that is coded as 1 for 'male' and 0 for 'female'. \\
\hline Duration in AIM & $\begin{array}{l}\text { Monthly duration that respondent is becoming members of AIM and receive } \\
\text { microcredit support from AIM. }\end{array}$ \\
\hline $\begin{array}{l}\text { Income gained when } \\
\text { joining AIM }\end{array}$ & $\begin{array}{l}\text { Yearly income and per capita yearly income of respondents after they involve in } \\
\text { the AIM program. The per capita annual income is defined as yearly income per } \\
\text { household size. }\end{array}$ \\
\hline Ability to pay zakat & $\begin{array}{l}\text { A dummy variable. Binary number of ' } 0 \text { ' (not able to pay zakat) and ' } 1 \text { ' (able to } \\
\text { pay zakat). }\end{array}$ \\
\hline $\begin{array}{l}\text { Amount of loan/ } \\
\text { microcredit received }\end{array}$ & $\begin{array}{l}\text { Value of loan received by members of AIM when they involved with the } \\
\text { microfinance scheme in Ringgit Malaysia (RM) (transformed into natural log) }\end{array}$ \\
\hline Value of assets & $\begin{array}{l}\text { Total value of all assets belong to members of AIM while receiving the microcredit } \\
\text { which could be in term of land, house, vehicles or others in Ringgit Malaysia (RM) } \\
\text { (transformed into natural log) }\end{array}$ \\
\hline $\begin{array}{l}\text { Ratio of spending to } \\
\text { income }\end{array}$ & $\begin{array}{l}\text { The proportion of spending by respondents from the income received from the } \\
\text { project financed by AIM per month }\end{array}$ \\
\hline
\end{tabular}

Source: Authors' list

The present study adopts two methods of analysis on the collected data. First, descriptive analysis is conducted with the use of frequencies and cross-tabulation. In cross-tabulation, a similar Chi-Squared test could also be used to test for relatedness or independence between variables. Pearson chi-square and the likelihood-ratio chi-square are used for the test. Furthermore, the present study uses a nonlinear regression specifically uses binary dependent variable. The model is developed to test the probability/likelihood that the respondents pay zakat. It is called logistic regression that adopts a nonlinear formulation that forces the predicted values to be between 0 and 1 by using cumulative probability distribution function (c.d.f.), denoted by F. This logistic cumulative distribution function has a specific functional form, defined in terms of the exponential function. The population logit model is written as: 


$$
\begin{aligned}
& \operatorname{Pr}\left(Y=1 \mid X_{1}, X_{2} \ldots \ldots \ldots\right)=F\left(\beta_{0}+\beta_{1} X_{1}+\beta_{2} X_{2}+\ldots \ldots .+\beta_{k} X_{k}\right) \\
& =\frac{1}{1+\mathrm{e}^{-\left(\beta_{0}+\beta_{1} X_{1}+\beta_{2} X_{2}+\ldots .+\beta_{k} X_{k}\right)}}
\end{aligned}
$$

For the current study, a logit model could be written as follows:

$\mathrm{L}_{\mathrm{i}}(\mathrm{Y})=\mathrm{b}_{0}+\mathrm{b}_{1}\left(\mathrm{X}_{1}\right)+\mathrm{b}_{2}\left(\mathrm{X}_{2}\right)+\mathrm{b}_{3}\left(\mathrm{X}_{3}\right)+\mathrm{b}_{4}\left(\mathrm{X}_{4}\right)+\mathrm{b}_{5}\left(\mathrm{X}_{5}\right)+\mathrm{b}_{6}\left(\mathrm{X}_{6}\right)+\mathrm{b}_{7}\left(\mathrm{X}_{7}\right)$

Where $\mathrm{Li}$ is a dummy variable (value of 0 or 1 ). The independent variables included are marital status $\left(\mathrm{X}_{1}\right)$, level of income after joining AIM $\left(\mathrm{X}_{2}\right)$, level of education $\left(\mathrm{X}_{3}\right)$, gender $\left(\mathrm{X}_{4}\right)$, age $\left(\mathrm{X}_{5}\right)$, dummy for state $\left(\mathrm{X}_{6}\right)$, household size $\left(\mathrm{X}_{7}\right)$ and others. Once the regression made, the antilog of the slope coefficients $(\beta$ 's) subtract one from it and multiply by 100 will provide the percent change in the odds for a unit increase in the jth regressor. This percentage change could be interpreted, as probability that respondent will opt to pay zakat due to a unit increase in independent variables.

Instead of using $\mathrm{R}^{2}$ to measure the goodness fit of the model, it is suggested that another measure of fit should be adopted, namely "fraction correctly predicted'. Pearson ${ }^{2}$-type tests of goodness-of-fit, namely Hosmer \& Lemeshow (1989). For this test, poor fit indicated by a significance value less than 0.05 . Two pseudo R-squares are reported, namely, Cox and Snell R-square and Nagelkerke R-square. Both values provide an indication of the amount of variation in the dependent variables explained by the model (range from 0 to 1 ).

\section{Result and Discussion}

Description of sample respondents is displayed in Table 2. Majority of AIM participants in both states are women. From total number of respondents, 89.6 percent is female and 2.6 percent is male (7.8 percent is missing data). In Kelantan, all respondents (100 percent) are women. Total respondents from Perak are 1000 (51 percent) and 961 are from Kelantan. It is found that majority of respondents are having formal education. About 10.9 percent (213 respondents) do not have any formal education. 51.5 percent of respondents obtained primary level of education and 26.4 percent obtained secondary level of education (Sijil Pelajaran Malaysia or SPM). About 2.0 percent of them went to Malaysian high schools (Sijil Tinggi Persekolahan Malaysia or STPM/diploma/certificate/ pre-university) and 0.1 percent obtained a bachelor degree or higher. Nonetheless, 81.8 percent of respondents are married and only 5.2 percent are single or divorced.

Table 2. Frequencies and Percentages of Respondents by Gender, States, Marital Status, Ethnicity, Levels of Education and Religion

\begin{tabular}{lccc}
\hline & Item & Frequency & Percent \\
\hline \multirow{2}{*}{ Gender } & Male & 51 & 2.6 \\
& Female & 1758 & 89.6 \\
& Missing data & 152 & 7.8 \\
\multirow{2}{*}{ State } & Kelantan & 961 & 49.0 \\
& Perak & 1000 & 51.0 \\
\hline
\end{tabular}




\begin{tabular}{lccc}
\hline Item & & Frequency & Percent \\
\hline Ethnicity & Malay & 1727 & 88.1 \\
& Chinese & 7 & 0.4 \\
& Indian & 60 & 3.1 \\
& Others & 3 & 0.2 \\
Religion & Missing data & 164 & 8.4 \\
& Muslim & 1730 & 88.2 \\
& Christian & 4 & 0.2 \\
Buddha & Hinduism & 10 & 0.5 \\
Marital Status & Missing data & 54 & 2.8 \\
& Single/Divorced & 163 & 8.3 \\
& Married & 102 & 5.2 \\
Educational Level & Missing data & 1605 & 81.8 \\
\hline & No formal education & 254 & 13.0 \\
Primary education & 213 & 10.9 \\
Secondary education & 1010 & 51.5 \\
\hline
\end{tabular}

Source: Authors' Computation

Nevertheless, the test of relatedness or independence between the variables in crosstabulation is conducted using Chi-square statistic. The test is conducted to explore the relationship between two categorical variables. It compares the observed frequencies or proportions of cases that occur in each of the categories, with the values that would be expected if there were no association between the two variables being measured. Following are the hypotheses:

Hypotheses 1

$\mathrm{H}_{\mathrm{o} 1}$ : Gender is independent on level of education

$\mathrm{H}_{\mathrm{a} 1}$ : Gender is dependent on level of education

Hypotheses 2

$\mathrm{H}_{\mathrm{o} 2}$ : Gender is independent of marital status

$\mathrm{H}_{\mathrm{a} 2}$ : Gender is dependent on marital status

Hypotheses 3

$\mathrm{H}_{\mathrm{o} 3}$ : Gender is independent of states (either Kelantan or Perak).

$\mathrm{H}_{\mathrm{a} 3}$ : Gender is dependent on states (either Kelantan or Perak). 
Table 3. Cross Tabulation Statistics of Demographic Variables

\begin{tabular}{|c|c|c|c|c|}
\hline & & \multicolumn{2}{|c|}{ Gender } & \multirow{2}{*}{$\begin{array}{c}\text { Pearson Chi-square } \\
\text { value }\end{array}$} \\
\hline & & Female & Male & \\
\hline \multirow[t]{2}{*}{ State } & Perak & $949(94.9)$ & $51(5.1)$ & \multirow{2}{*}{$\begin{array}{c}42.456 \\
\text { (sig. } 0.000)\end{array}$} \\
\hline & Kelantan & $809(100.0)$ & $0(0.0)$ & \\
\hline \multirow[t]{2}{*}{ Marital Status } & Married & $1561(97.4)$ & $42(2.6)$ & \multirow{2}{*}{$\begin{array}{c}1.046 \\
\text { (sig. } 0.306)\end{array}$} \\
\hline & Single/Divorced & $101(99.0)$ & $1(1.0)$ & \\
\hline \multirow{5}{*}{$\begin{array}{l}\text { Level of } \\
\text { Education }\end{array}$} & No formal education & 210 (98.6) & $3(1.4)$ & \multirow{5}{*}{$\begin{array}{c}2.854 \\
\text { (sig. } 0.583)\end{array}$} \\
\hline & Primary education & $976(96.6)$ & $34(3.4)$ & \\
\hline & Secondary education & $505(97.5)$ & $13(2.5)$ & \\
\hline & $\begin{array}{l}\text { Certificate/STPM/Diploma/pre- } \\
\text { university }\end{array}$ & $39(97.5)$ & $1(2.5)$ & \\
\hline & Bachelor degree and above & $2(100.0)$ & $0(0.0)$ & \\
\hline
\end{tabular}

Note: Percent in parentheses.

Source: Authors' Computation

The Pearson Chi-square statistics in Table 3 indicate that gender is only dependent on state with p-value (sig.) lower than 5 percent. But gender is independent of level of education and marital status. This implies significant difference of male and female respondents' distribution in either Perak or Kelantan. In fact, all respondents in Kelantan are basically female.

Table 4. Descriptive Statistics on Continuous Variables

\begin{tabular}{lccccc}
\hline \multicolumn{1}{c}{ Variable } & N & Minimum & Maximum & Mean & Standard deviation \\
\hline Age & 1808 & 19.00 & 85.00 & 45.52 & 11.36 \\
Household size & 1955 & 1.00 & 18.00 & 5.96 & 2.46 \\
Yearly income (RM) & 1959 & 0.00 & 264000.00 & 23841.5 & 21266.3 \\
Yearly Per capita income (RM) & 1953 & 0.00 & 60000.00 & 4734.4 & 5102.7 \\
Duration in AIM (month) & 1798 & 1.00 & 372.00 & 56.8 & 46.8 \\
Ratio of spending to income & 1931 & 0.00 & 189.48 & 0.85 & 5.53 \\
Value of asset (RM) & 1774 & 0.00 & 420000.00 & 13412.61 & 26758.8 \\
Value of loan (RM) & 1958 & 200 & 22000.00 & 3533.86 & 2692.1 \\
\hline
\end{tabular}

Source: Authors' Computation

Table 4 shows the descriptive statistics for the continuous data/variables of the current study. The minimum age of respondents is 19 years old and the maximum age is 85 years old. On average, the age of respondents is 46 years old. As of the household size, the minimum size is one and the maximum size is 18 , with the average size of 5.96. It is found that the minimum yearly income received by respondents from AIM program is zero 
and the maximum of yearly income received is RM 264,000.00. On average, approximately RM 23,851.77 income per year received by respondents. The amount of per capita income per year is also calculated by dividing income per year by household size. The results show that about RM 60,000.00 is the maximum yearly per capita income of respondents, with the mean of RM 4,734.40. As for the ratio of spending to income (after joining AIM), the mean percentage of spending per income is about 85 percent. The minimum value of loan obtained from AIM scheme among respondents is RM200.00 and the maximum is RM 22,000.00. Meanwhile, the value of assets belong to respondents, the maximum is RM 420,000.00. Looking at the standard deviation of the data, it is found that there is less variance of data for age, household size and ratio of spending to income due to small number of standard deviation.

Table 5. Ability of pay zakat from the project returns

\begin{tabular}{lccccc}
\hline \multicolumn{1}{c}{ Item } & $\begin{array}{c}\text { Strongly Disagree } \\
\text { (SDA) }\end{array}$ & $\begin{array}{c}\text { Disagree } \\
\text { (DA) }\end{array}$ & $\begin{array}{c}\text { Neutral / } \\
\text { indifferent }\end{array}$ & $\begin{array}{c}\text { Agree } \\
\text { (A) }\end{array}$ & $\begin{array}{c}\text { Strongly } \\
\text { Agree (SA) }\end{array}$ \\
\hline $\begin{array}{l}\text { I am able to pay zakat } \\
\text { after joining AIM }\end{array}$ & $6(0.3)$ & $312(17.3)$ & $451(25.0)$ & $895(49.6)$ & $139(7.7)$ \\
\hline
\end{tabular}

Notes: Valid Percentage in parentheses

Source: Authors' Computation

The respondents are asked on their ability to pay zakat since they joined AIM. The results are displayed on Table 5. It is found that majority of participants of AIM are able to pay zakat after they joined the scheme (57.3 percent). However, quite substantial amount of them are not able to pay zakat from the returns of the projects that is about 42.7 percent.

Next, the current study aims to analyze factors contribute significantly to the likelihood (probability) of paying zakat among respondents who received micro-credit from AIM. Adopting logistic regression to predict categorical outcomes with two or more categories, the independent variables can be either categorical or continuous, or a mix of both. The Binary Logistic model is used for the current data, in which the dependent variable has only two categories, one and zero. Value one is recorded to the responses of ' 1 (strongly agree) and 2(agree)' for the survey question 'Do you able to pay zakat every year?' and value zero is recorded to the response of ' 3 (neutral), 4(disagree) and 5(strongly disagree)' on the same question. Demographic variables such as gender, household size, age; marital status, education level and income after involving in AIM program are the independent variables in the model. The study is using 'yearly per capita income (RM)' for income level after joining AIM, which later transformed into natural log. The independent variables are also consisting of dummy variables such as marital status ( $1=$ married, $0=$ otherwise), gender ( $1=$ male, $0=$ female $)$ and dummy of state $(1=$ Kelantan, $0=$ otherwise $)$ as well as continuous variables such as household size, age, income level, and level of education. The results are displayed on Table 6.

The regression results in Table 6 display significant variables of 'Dummy of state', 'household size', 'education level' and 'per capita yearly income' in the model. The negative 
coefficient $(\beta)$ of household size, which is -0.101 , indicates that an increase in household size, results in a decrease probability of scoring 1 in the dependent variable (ie. paying zakat). The odd ratio $(\operatorname{Exp}(\beta))$ for household size is 0.904 , which could be interpreted that the odds of a person paying zakat decreases by a factor of 0.904 , all other factors being equal. The variable of household size, reflected by number of dependents, is however found to be insignificant in a study by Wahid et al. (2005a) and several other studies. Thus, it is expected that for the poor respondents who receive microfinance scheme of AIM, size of family is significant to determine the ability for them to pay zakat from business return. Bigger family size incurs more spending and less income available to make zakat payment.

Table 6. Logistic Regression Results

\begin{tabular}{|c|c|c|}
\hline \multirow{3}{*}{ Independent variables } & \multicolumn{2}{|c|}{ Dependent variables: } \\
\hline & \multicolumn{2}{|c|}{ Paying zakat } \\
\hline & B & $\operatorname{Exp}(B)$ \\
\hline Constant & $\begin{array}{c}1.857 \\
(1.398)\end{array}$ & 6.407 \\
\hline Age & $\begin{array}{c}0.014 \\
(0.009)\end{array}$ & 1.014 \\
\hline Dummy Marital Status & $\begin{array}{l}-0.072 \\
(0.317)\end{array}$ & 0.931 \\
\hline Education Level & $\begin{array}{c}0.304^{* *} \\
(0.131)\end{array}$ & 1.355 \\
\hline Household Size & $\begin{array}{c}-0.101^{* * *} \\
(1.398)\end{array}$ & 0.904 \\
\hline Duration in Aim-Suppose to be AIM & $\begin{array}{l}-0.001 \\
(0.002)\end{array}$ & 0.999 \\
\hline Dummy State & $\begin{array}{c}-1.411^{* * *} \\
(0.176)\end{array}$ & 0.244 \\
\hline Ratio Spending to Income & $\begin{array}{c}0.131 \\
(0.081)\end{array}$ & 1.140 \\
\hline Nat. Log Value of Asset & $\begin{array}{l}-0.075 \\
(0.061)\end{array}$ & 0.928 \\
\hline Nat. Log Value of Loan & $\begin{array}{c}0.172 \\
(0.140)\end{array}$ & 1.188 \\
\hline Nat. Log Per Capita Yearly Income & $\begin{array}{c}-0.260^{* *} \\
(0.122)\end{array}$ & 0.771 \\
\hline
\end{tabular}

\section{Diagnostic tests}

$\begin{array}{lc}\text { \% correct classification } & 68.8 \\ \text { Omnibus Chi-square stat. } & 111.78^{* * *} \\ \text { Hosmer \& Lemeshow Test statistics } & 7.167 \\ \text { Cox \&Snell R-square } & 0.129 \\ \text { Negelkerke R-square } & 0.174\end{array}$

Notes: 1. Standard errors are in parentheses;

2 . ${ }^{* * *}$ statistically significant at the $1 \%$ level; ${ }^{* *} 5 \%$ level; ${ }^{*} 10 \%$ level.

Source: Authors' Computation 
For dummy of state, the coefficient is also significant at $1 \%$ level and negative. The negative sign of coefficient implies that the odds of paying zakat declines by a factor of 0.244 for respondents from Kelantan as compared to those from Perak, other things remain constant. The result is as expected as it is well known that Kelantan has large percentage of poor in Malaysia and the recipients of microfinance in this state might not get returns from small business activities as large as in other states that require them to pay zakat income.

The negative coefficient sign of natural log per capita yearly income indicates similar impact. The probability of paying zakat is higher among respondents with lower per capita yearly income as compared to those who have higher per capita yearly income. The negative relationship between income and willingness to pay zakat obtained in this study is somehow contrast to studies by Tahir \& Majid (1999), Nor Ghani et.al (2001), Wahid et al. (2005a), and Mahanani et.al (2018) who found positive relationship between these variables but the result is consistent to studies by Jaffar et al. (2011), Firdaus et.al. (2012), and Bakar \& Rashid (2010). In Firdaus et al. (2012), there is a tendency that higher income level tends to lead to lower payment made to formal institutions. Bakar \& Rashid (2010) found that lesser percentage of respondents pay zakat on income among higher income respondents. In the current study, we perceive that less willingness to pay zakat among those received more income from microfinance return is due to background of the recipients who are poor and they mainly focus on improving their spending from the returns of business activities.

On the other hand, the only positive and significant determinant is education level with the odd ratio more than one. The coefficient reflects that probability of paying zakat is bigger among higher education respondents. The odd ratio $(\operatorname{Exp}(\beta))$ of 1.355 could be interpreted that the odds of a respondent paying zakat increases by a factor of 1.355 among higher education respondents, all other factors being equal. Similar results obtained by Firdaus et.al (2012) when they found that $\mathrm{PhD}$ holders occupy the highest percentage of the respondents paying zakat through formal institution. Several studies (Saad et al., 2010; Jaffar et al., 2011) also indicated the importance of knowledge, reflected by higher education, as a driving factor for paying zakat.

Age, marital status and spending seem to be insignificant variables in the current regression. The insignificant age is also found in studies by Tajuddin et al. (2016) on factors influencing zakah compliance behaviour among youth in Klang Valley, Malaysia. Wahid et al (2005a), on the other hand, show age factor is significant with positive sign. Significant and positive factors of 'married' and 'spending' are also found in this study among Muslims from several states of Peninsula Malaysia. As the current study only focuses on the disadvantages participants of AIM, we foresee that the results are different from studies using alternative sampling. Nonetheless, value of assets and value of loan received also not contribute to the tendency of paying zakat among the respondents. Most of respondents have minimum asset value which basically inherited land and house they are living and the loan received largely used to sustain the current income for living which is very limited to pay zakat. Therefore, in summarization, the probability/likelihood of paying zakat among respondents is determined significantly by small household size, higher education level, lower per capita income and state. 
The classification table, with no predictor in the model, reports $57.7 \%$ of correctly classified cases. The inclusion of a set of independent variables does improve the accuracy of prediction to $68.8 \%$. The Omnibus test of Model coefficients are significant ( $\mathrm{p}$-value $<0.05$ ) which implies that the model with set of variables used as predictors is better than the model without predictors. The Chi-square statistic is 111.78 with 10 degree of freedom. This is also supported by Hosmer \& Lemeshow test of 'goodness of fit' of the model with Chi-square statistics of 7.167 (p-value more than 0.05). Besides, the pseudo R-square statistics (Cox \& Snell R-square and Nagelkerke R-square) show that between $13 \%$ and $17 \%$ of the variability in the dependent variable is explained by the set of independent variables in the model.

\section{Conclusion}

The present study looks at the probability of paying zakat among members of AIM, who received micro-credit from Amanah Ikhtiar Malaysia (AIM) to fund micro and small businesses. In methodology, a survey is conducted to collect primary data from a sample of participants of AIM program in Perak and Kelantan. The present study adopts two methods of analysis on the collected data. First, descriptive analysis is conducted with the use of frequencies and cross-tabulation. Second, the study also uses a nonlinear regression model specifically designed for binary dependent variables to analyze factors significantly determine the probability that the respondents pay zakat. Overall, the findings show that gender is dependent on state where the respondents living. But gender is independent from marital status and education level. Results from logistic regression indicate that the probability of paying zakat among respondents is determined significantly by small household size, higher education level, lower per capita income and those respondents living in Perak.

From the findings, the paper resorts to provide policy recommendations that may guide collection of zakat among participants of microfinance scheme under AIM and how the proceeds can be geared towards the needy. The recommendations are: First, there is a need to educate the microfinance participants on zakat requirement and zakat base and be exposed academically to the significance of zakat from spiritual, economic, and social perspective and appreciate its significance towards societal development through talks, seminars and conferences and even media chats. This is very important especially among low educated participants and those who obtain higher income/return from the projects as well as those participants stay in Kelantan. Second, efforts should be taken by both AIM and zakat institutions to well develop good and efficient methods of zakat collection among AIM participants such as yearly income deduction on the returns from projects that exceed nisab. These efforts should also be widened to other microfinance participants. Third, policy makers such as government and Zakat Centre must play a more effective and efficient role in distributing zakat income. Once the zakat payers notice the significant roles play by the zakat institutions, they will voluntarily contribute their income to zakat institutions regularly. Fourth, it might be desirable too from AIM's side to stop giving funds to the microfinance participants who fail to pay zakat from returns of their businesses. 


\section{References}

Abdullah, L., \& Wan Ahmad, W. M. (2012). Juristic Discourse on the Delay in Payment and Distribution of Zakat. Middle East Journal of Scientific Research, 12(2), 176-181.

Abdullah, M., \& Sapiei, N. (2018). Do Religiosity, Gender and Educational Background Influence Zakat Compliance? The Case of Malaysia. International Journal of Social Economics, 45(8), 1250-1264.

Abdullah, R. (2010). Zakat management in Brunei Darussalam: A case study. In Proceedings of Seventh International Conference The Tawhidi Epistemology: Zakat and Waqf Economy. Bangi, Malaysia. 375-407.

Ab. Rahman, A., \& Omar, S. M. N. (2010). Tauhid Epistemology in Increasing the Number of Zakat of Wealth Payers and Its Contribution toward the Development of Malaysia Economy. In Proceedings of Seventh International Conference The Tawhidi Epistemology: Zakat and Waqf Economy. Bangi, Malaysia. 53-63.

Aidit, G. (1998). Zakat-Satu Tinjauan (Zakat-One Review). Petaling Jaya, Malaysia: IBS Buku Sdn. Bhd.

Ali, E. M. T. E., Rahman, S. M. A. S. A., Baba, Z. S., \& Muda, H. (2018). The Employees' Awareness on the Monthly Zakat Deduction Scheme in Terengganu. International Journal of Academic Research in Business and Social Sciences, 8(7), 999-1010.

Ali, M. N. M., Hairunnizam, W. \& Nor Ghani, M.N. (2003). Kesedaran Membayar Zakat Pendapatan kakitangan Professional: Kajian Kes di UKM (Awareness of Paying Zakat on Professional Employee Income: A Case Study in UKM). Seminar Kebangsaan Dasar Awam Dalam Era Globalisasi: Penilaian Semula Ke Arah Pemantapan Strategi. 16-17 September. Bangi, Malaysia.

Al-Qardawi, Y. (1993). Fiqh Zakat (Fiqh of Zakat). Jakarta: Litera AntarNusa.

Al-Qardawi, Y. (1998). Peranan Nilai dan Akhlak dalam Ekonomi Islam (The Role of Values and Morals in Islamic Economics). Kuala Lumpur: Metacorp Bhd.

Ayuniyyah, Q. (2011). Factors Affecting Zakat Payment Through Institution of Amil: Muzakki’s Perspectives Analysis - Case Study of Badan Amil Zakat Nasional (BAZNAS). Jurnal Ekonomi Islam Al-Infaq, 2(2), 49-64.

Bakar, N. B. A., \& Rashid, H. M. A. (2010). Motivations of Paying Zakat on Income: Evidence from Malaysia. International Journal of Economics and Finance, 2(3), 76-84.

Cokrohadisumarto, W. M., Zaenudin, Z., Santoso, B., \&Sumiati, S. (2019). A Study of Indonesian Community's Behaviour in Paying Zakat. Journal of Islamic Marketing, 11(4), 961-976. https://doi.org/10.1108/JIMA-10-2018-0208.

Firdaus, M., Beik, I. S., Irawan, T., \& Juanda, B. (2012). Economic Estimation and Determinations of Zakat Potential in Indonesia. Jeddah: Islamic Research and Training Institute.

Furqani. H, Mulyany. R, and Yunus. F. (2018). Zakat for Economic Empowerment of the Poor in Indonesia: Models and Implications. Jurnal Kajian Ekonomi dan Binis Islam, 11(2), 392- 411. 
Ghani, E. K., Aziz, A. A., Tajularifin, S. M., \& Samargandi, N. (2018). Effect of Board Management and Governmental Model on Zakat Payers' Trust on Zakat Institutions. Global Journal Al-Thaqafah, (Special Issue), 73-86.

Hafidhuddin, D. (2002). Zakat Dalam Perekonomian Modern (Zakat in the Modern Economy). Jakarta: Gema Insani Press.

Hassan, M. K. (2010). An Integrated Poverty Alleviation Model Combining Zakat, Awqaf and Micro-Finance. In Proceeding Seventh International Conference The Tawhidi Epistemology: Zakat and Waqf Economy. Bangi, Malaysia. 261-281.

Hosmer, D. W., \& Lemeshow, S. (1989). Apllied Logistic Regression. New York: John Wiley $\&$ Sons.

Idris. K.M. (2006). Efek Persepsi Undang-Undang dan Penguatkuasaan Zakat terhadap Gelagat Kepatuhan Zakat Pendapatan Gaji (Effects of Legal Perception and Zakat Enforcement on Salary Income Zakat Compliance Behavior). Journal of Ethics, Legal and Governance, 2, 32-41.

Ismail, S. B. H., Jogeran, J. B., Noor, A. H. M. (2012). Determinant Factors of Paying Zakat On Employment Income By Government Servants in Malaysia. International Conference on Islamic Economy and Business.

Jaffar, M. A. , Affif, A., Amri, H. and Sahezan, C. N., (2011). A Study on the Factors Attribute to Non Participation of Zakat Income Among the Muslim Community in Selangor. 2nd International Conference on Business and Economic Research, 14-16 March 2011, Langkawi, Kedah, Malaysia.

Kamil, M.I. (2005). The Role of Intrinsic Motivational Factors on Compliance Behaviour of Zakat on Employment Income, in Isu-isu Kontemporari Zakat di Malaysia (1st ed.), 137-170, Melaka: UiTM.

Kassim S., Kassim S.N., Othman N. (2019). Islamic Microfinance in Malaysia: Issues and Challenges. In: Mat Noor A., Mohd Zakuan Z., Muhamad Noor S. (Eds). Proceedings of the Second International Conference on the Future of ASEAN (ICoFA) 2017, Vol. 1. Singapore: Springer, 367-377.

Khamis, M. R., \&Yahya, N. C. (2015). Does Law Enforcement Influence Compliance Behaviour of Business Zakat among SMEs?: An Evidence via Rasch Measurement Model. Global Journal Al Thaqafah, 5(1), 19-32.

Lunn, J., Klay, R. \& Douglass, A. (2001). Relationship among Giving, Church Attendance, and Religious Belief: The Case of the Presbyterian Church (USA). Journal for the Scientific Study of Religion, 40(4), 765-775.

Mahanani, Y., Novianti, T., Wiliasih, R., \& Kassim, S. (2018). Factors Affecting Employees' Preference to Pay Zakat: Case of Amil Zakat Institution of Bogor Agricultural University. Proceeding International Conference of Zakat 2018, 15-16 November, Universitas Gadjah Mada, Yogyakarta, Indonesia.

Mokhtara, S. S. B. S., Mahomeda, A. S. B. B., \& Hashima, H. (2018). The Factors Associated with Zakat Compliance Behaviour Among Employees. International Journal of Economics and Management, 12(Special Issue 2), 687-696 . 
Mujiyati, B. R., \& Sholahuddin, M. (2010). Some Influence Factors of Zakat-InfaqShadaqah collecting: A Case in Surakarta, Central Java, Indonesia. In Proceedings of Seventh International Conference The Tawhidi Epistemology: Zakat and Waqf Economy. Bangi, Malaysia. 435-445.

Nor Ghani, M. N., Mariani, M., Jaafar, A., \& Nahid, I. (2001). Can Privatization Improve Performance? Evidence from Zakat Collection Institutions. Islamic Economy Workshop. Faculty of Economics, Universiti Kebangsaan Malaysia, Bangi, Malaysia.

Othman, Y., Yusuff, M. S. S., \& Latib, M.F.A. (2018). Motivations for Paying Income Zakat among UniSHAMS’ Employees. International Journal of Academic Research in Business and Social Sciences, 8(10), 619-628.

Reinstein, D. (2006). Does One Contribution Come at the Expense of Another? Empirical Evidence on Substitution Between Charitable Donations. Economics Discussion Papers. University of Essex.

Saad, R. A. J., Bidin, Z., Md. Idris, K., \& Md. Hussain, M.H. (2010). Faktor-Faktor yang Mempengaruhi Gelagat Kepatuhan Zakat Perniagaan (Factors Affecting Business Zakat Compliance Behavior). Management Journal, 30, 49-61.

Saad, R. A. J., Farouk, A. U., Wahab, M. S. A., \& Ismail, M. (2019). What Influence Entreprenuer to Pay Islamic Tax (Zakat)?. Academy of Entrepreneurship Journal, 25(1), $1-13$.

Saad, R. A. J., Farouk, A. U., \& Kadir, D. A. (2020). Business Zakat Compliance Behavioral Intention in a Developing Country. Journal of Islamic Accounting and Business Research, 11(2), 511-530. https://doi.org/10.1108/JIABR-03-2018-0036.

Sanusi, N. A., Wahab, N. A. A. \& Bahar, N. F. M. (2005). Gelagat Kepatuhan Pembayaran Zakat Pendapatan: Kajian Kes UUM (Income Zakat Payment Compliance Behavior: A Case Study of UUM). Proceeding of Seminar Ekonomi dan Kewangan Islam, 29-30 August 2005, Fakulti Ekonomi, Universiti Utara Malaysia, Kedah, Malaysia.

Tahir, M. Z. \& Majid, M. (1999). Prestasi Kutipan dan Agihan Zakat di Malaysia (Zakat Collection and Distribution Performance in Malaysia). In Proceeding Seminar Pengeluaran Awam dan Swasta: Justifikasi dan Realiti di Malaysia. Universiti Kebangsaan Malaysia. 293-306

Tajuddin, T. S., Azman, A.S. \& Shamsuddin, N. (2016). Zakat Compliance Behaviour on Income among Muslim Youth in Klang Valley. Shariah Journal, 24(3), 445-464

The Star. (2017). Microfinance in Malaysia Benefits over 1 Million Enterprises. Retrieved from https:/www.thestar.com.my/business/business-news/2017/05/22/microfinance-inmalaysia-benefits-over-1-million-enterprises/

Wahid, H., Noor, M.A.M., Ahmad, S. (2005a). Kesedaran Membayar Zakat: Apakah Faktor Penentunya? (Awareness of Paying Zakat: What Are the Determining Factors?). International Journal Management Studies, 12(2), 171-189.

Wahid, H., Ahmad, S. \& Noor, M.A.M. (2005b). Kesedaran Membayar Zakat Pendapatan di Malaysia (Awareness of Paying Income Zakat in Malaysia.). Islamic Economic and Finance Seminar. Universiti Utara Malaysia. 29-30 August, 265-274. 